\title{
AGRONOMIC PERFORMANCE AND BIOLOGICAL EFFICIENCY OF KALE INTERCROPPED WITH SPICE SPECIES ${ }^{1}$
}

\author{
ANA RÉGIA ALVES DE ARAÚJO HENDGES ${ }^{2 *}$, MARCELO DE ALMEIDA GUIMARÃES ${ }^{3}$, JÚLIO CÉSAR \\ DOVALE $^{3}$, BENEDITO PEREIRA LIMA NETO ${ }^{3}$
}

\begin{abstract}
Intercropping is a management strategy for the sustainability of agricultural systems, and is suitable for the production of vegetables. Kale is predominantly grown singly, but field observations have indicated that this crop has satisfactory productive potential when grown in intercrops with other vegetables. The objective of this work was to evaluate the agronomic performance and biological efficiency of kale plants intercropped with spice species. The experiment was carried out at the Didactic Horta of the Federal University of Ceará, Fortaleza, state of Ceará, Brazil. The experiment was conducted in a randomized block design with five replications. The treatments consisted of kale grown singly and intercropped with spice species (chives, coriander, basil, and parsley) and these spice species grown singly. The fresh and dry weights of the kale leaves, and the shoot of the spice species were evaluated. The biological efficiency was evaluated by the land use efficiency index (LUE), relative contribution of the kale crop to the LUE, area time equivalent ratio, and system productivity index. The intercropping of kale with parsley resulted in the highest fresh, and dry weights of kale leaves, showing the highest agronomic efficiency.
\end{abstract}

Keywords: Brassica oleracea L. var. acephala. Intercropping. Sustainable agriculture. Land use efficiency.

\section{DESEMPENHO AGRONÔMICO E EFICIÊNCIA BIOLÓGICA DE COUVE CONSORCIADA COM PLANTAS CONDIMENTARES}

RESUMO - A consorciação de culturas é uma estratégia de manejo que visa a sustentabilidade dos agrossistemas, sendo adequada à produção de hortaliças. A couve é preponderantemente manejada sob cultivo solteiro, mas observações de campo tem indicado que a cultura tem potencial produtivo satisfatório quando cultivada em consórcio com outras hortaliças. Neste trabalho, avaliou-se o desempenho produtivo e a eficiência biológica do consórcio de couve com espécies condimentares. O experimento foi realizado na Horta didática da Universidade Federal do Ceará, Fortaleza - CE. Os tratamentos consistiram do cultivo de couve solteira e consorciada com espécies condimentares (cebolinha, coentro, manjericão e salsa), bem como seus respectivos cultivos solteiros. O delineamento experimental utilizado foi blocos ao acaso, com cinco repetições. Avaliou-se as massas fresca e seca das folhas de couve e da parte aérea para as espécies condimentares. A eficiência biológica foi avaliada pelo índice de uso eficiente da terra, contribuição relativa da cultura de couve ao UET, razão de área equivalente no tempo e índice de produtividade do sistema. O consórcio com salsa resultou nas maiores produções de massas fresca e seca de folhas de couve, mostrando-se com a maior eficiência agronômica.

Palavras-chave: Brassica oleracea L. var. acephala. Consorciação de culturas. Eficiência agronômica. Uso eficiente da terra.

\footnotetext{
*Corresponding author

${ }^{1}$ Received for publication in 03/09/2017; accepted in 09/26/2018.

Paper extracted from the master dissertation of the first author.

${ }^{2}$ Instituto Federal de Educação, Ciência e Tecnologia do Maranhão, São Raimundo das Mangabeiras, MA, Brazil; ana.alves@ifma.edu.br ORCID: 0000-0002-8491-8382.

${ }^{3}$ Department of Plant Science, Universidade Federal do Ceará, Fortaleza, CE, Brazil; mguimara@ufc.br - ORCID: 0000-0002-5329-022X, juliodovale@ufc.br - ORCID: 0000-0002-3497-9793, benepneto@hotmail.com - ORCID: 0000-0003-0279-058X.
} 


\section{INTRODUCTION}

Managing plant diversity is one of the main strategies to achieve sustainability in agricultural systems (MARKOVIC, 2013). Intercropping is one of the practices for this diversification, and the most accessible and suitable managements for vegetable crops (MONTEZANO; PEIL, 2006).

Intercropping is an agroecological technique in which two or more species are grown in the same area for a certain period of time (BROOKER et al., 2015). Intercropping systems improve the use of productive resources (GRANGEIRO et al., 2011), stability of production (CARVALHO et al., 2009), and increased profitability per area (CECÍLIO FILHO et al., 2010).

Intercropping is usually association of a main culture of economic interest with another crop (BRANTHA; SERAN, 2009) that also present economic interest or some advantage to the production process of the main culture. However, these species should be complementary to each other regarding the use of productive resources (FONSECA, 2009; MOUSAVI; ESKANDARI, 2011).

This complementarity requires that species growth patterns are different in time and space (BRINTHA; SERAN, 2009) to minimize of interspecific competition for environmental resources (water, light, and nutrients), and possible allelopathic effects (PINTO; PINTO, 2012). These conditions generate a more balanced growth of the species, and, therefore, the maximization of the productivity in intercropping systems (ALBUQUERQUE et al., 2012).

The effectiveness of the intercrop is dependent on the choice of associations between species based on several factors, such as plant growth and development, productive indexes (SOUZA; MACEDO, 2007), and biological efficiency (PINTO et al., 2011). In the case of vegetables, several researches involving different species have already been carried out; most of them have showed the higher agronomic performance of intercrops when compared to crop grown singly (OLIVEIRA et al., 2010).

However, few scientific studies report intercrops with Brasicaceae species, such as Brassica oleracea. These works were carried out with broccoli
(B. oleracea var. italica) and lettuce (Lactuca sativa) (OHSE et al., 2012), cabbage (B. oleracea var. capitala) and garden nasturtium (Tropaeolum majus) (MORAES et al., 2008), kale (B. oleracea var. acephala) and coriander (Coriandrum sativum) (RESENDE et al., 2010), and kale and New Zealand spinach (Tetragonia expansa) (BIANCO, 2015). The results of these works showed that the production of kale in intercropping systems is technically feasible.

Thus, the objective of this work was to evaluate the agronomic performance and biological efficiency of kale plants intercropped with spice species chives (Allium fistulosum), coriander (Coriandrum sativum), basil (Ocimum basilicum) and parsley (Petroselinum crispum).

\section{MATERIAL AND METHODS}

The experiment was conducted from August to November 2015, at the Diadactic Horta, Department of Plant Science, Federal University of Ceará (UFC), Fortaleza, CE, Brazil (03044'24"S, $38^{\circ} 34^{\prime} 35^{\prime \prime} \mathrm{W}$, and altitude of $\left.21 \mathrm{~m}\right)$. The climate of the region is As, tropical with dry summer, according to the classification of Köppen (ALVARES et al., 2013). The experiment period had mean temperature of $28.1{ }^{\circ} \mathrm{C}\left(22.8\right.$ to $\left.31{ }^{\circ} \mathrm{C}\right)$, relative humidity of $66.6 \%$, and accumulated rainfall of $11 \mathrm{~mm}$. The soil of the experiment area was a Red-Yellow Argissolo (SANTOS et al., 2013); it presented pH (water) = $6.3 ; \mathrm{P}=215.3 \mathrm{mg} \mathrm{dm}^{-3} ; \mathrm{K}=310.0 \mathrm{mg} \mathrm{dm}^{-3} ; \mathrm{Ca}^{2+}=$ $12.7 \mathrm{cmolc} \mathrm{dm}^{-3} ; \mathrm{Mg}^{2+}=7.6 \mathrm{cmolc} \mathrm{dm}^{-3} ; \mathrm{Al}^{3+}=0.0$ cmolc dm ${ }^{-3} ; \mathrm{H}+\mathrm{Al}=1.9 \mathrm{cmolc} \mathrm{dm}^{-3}$; sum of bases $(\mathrm{SB})=21.7 \mathrm{cmolc} \mathrm{dm}^{-3}$, cation exchange capacity $(\mathrm{CEC})=23.8 \mathrm{cmolc}^{-3}$, saturation by bases $(\mathrm{V})=$ $92.0 \%$ and organic matter $(\mathrm{OM})=65.8 \mathrm{~g} \mathrm{~kg}^{-1}$.

A randomized block experimental design was used, with nine treatments and five replications. The treatments consisted of kale grown singly and intercropped with chives, coriander, basil and parsley and of the respective single crop of these spice species.

The experimental plots consisted of areas of $1.2 \mathrm{~m} \times 2.4 \mathrm{~m}$. The spacings used were $0.60 \times 0.60$ $\mathrm{m}$ for kale, $0.20 \times 0.10 \mathrm{~m}$ for chives, $0.20 \mathrm{~m}$ between rows with seeding density of $4 \mathrm{~g} \mathrm{~m}^{-1}$ for coriander and parsley and $0.60 \times 0.25 \mathrm{~m}$ (intercrop) and $0.30 \mathrm{x}$ $0.25 \mathrm{~m}$ (monoculture) for basil (Figure 1). 

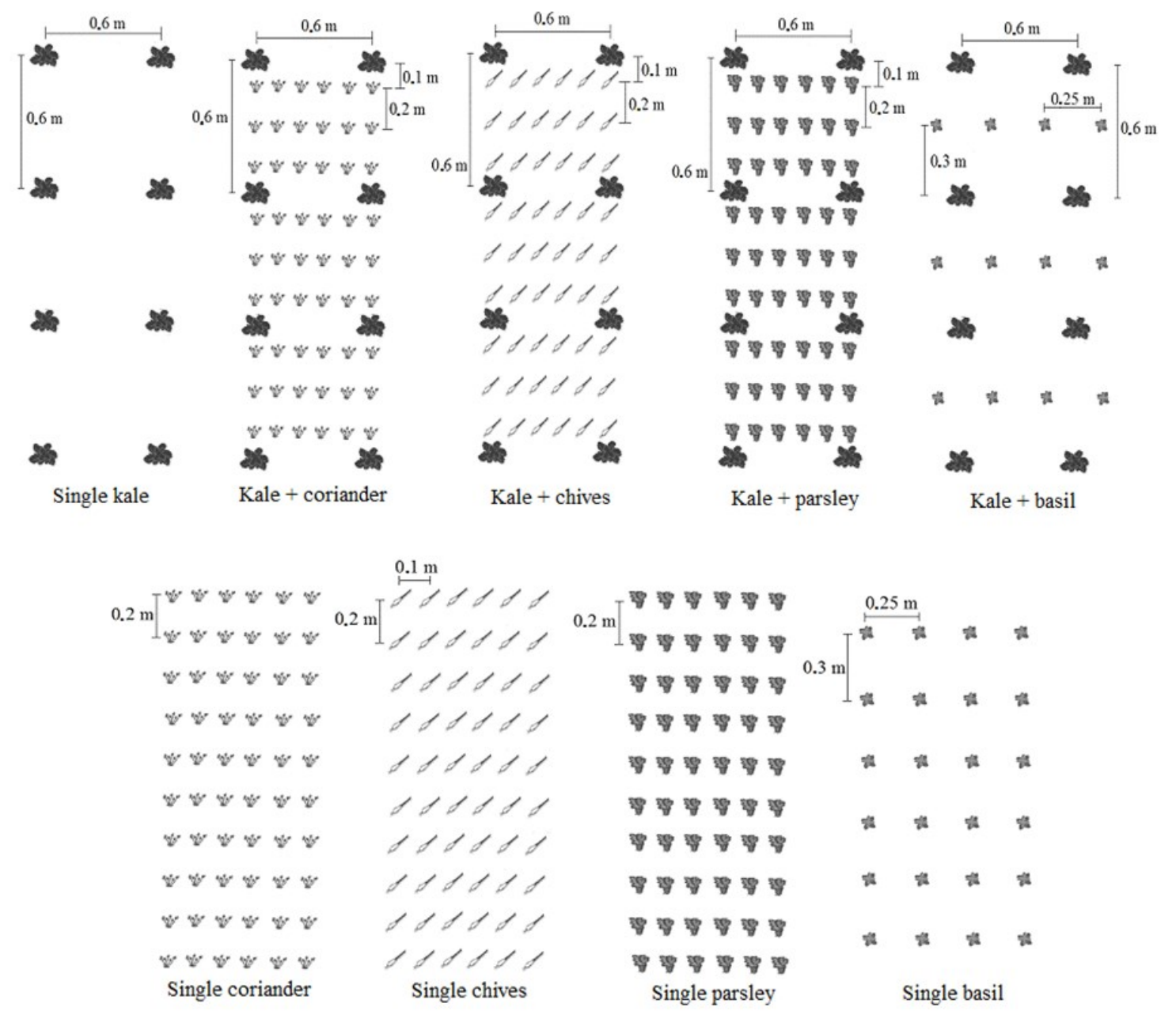

Figure 1. Spacings used in treatments with kale and spice species grown singly or intercropped with kale plants.

In intercropping, the kale rows were alternated with three rows of spice crops for chives, coriander and parsley (totaling nine rows of spice crops per plot). The intercropping of kale with basil was implemented with basil between all kale rows, totaling three rows per plot (12 basil plants). The evaluated plants of the treatments with kale consisted of the four central plants (monocultures) and the spice plants between them (intercropping). The evaluated plants of the treatments with spice plants grown singly consisted of the four central rows for chives, coriander, and parsley, and the two central rows for basil.

The soil of the experiment area was fertilized with $12 \mathrm{~kg} \mathrm{~m}^{-2}$ of organic compost produced with $75 \%$ of dry plant material and $25 \%$ bovine manure. The organic compound presented $\mathrm{pH}$ in water of 6.9, $344.3 \mathrm{mg} \mathrm{dm}^{-3}$ of $\mathrm{P}, 230.0 \mathrm{mg} \mathrm{dm}^{-3}$ of $\mathrm{K} ; 10.9 \mathrm{cmolc}$ $\mathrm{dm}^{-3}$ of $\mathrm{Ca}^{2+}, 9.4 \mathrm{cmolc} \mathrm{dm}^{-3}$ of $\mathrm{Mg}^{2+}, 98 \mathrm{mg} \mathrm{dm}^{-3}$ of $\mathrm{Zn}, 21.1 \mathrm{mg} \mathrm{dm}^{-3}$ of Fe, $67.7 \mathrm{mg} \mathrm{dm}^{-3}$ of $\mathrm{Mn}, 0.7 \mathrm{mg}$ $\mathrm{dm}^{-3}$ of $\mathrm{Cu}$, and $1.6 \mathrm{mg} \mathrm{dm}^{-3}$ of $\mathrm{B}$.

Kale and basil were sowed in August 11, 2015, using 162-cell polypropylene trays filled with a substrate based on earthworm humus and vermiculite $\left(4: 1 \mathrm{v} \mathrm{v}^{-1}\right)$. The plants were transplanted at 20 (basil) and 23 (kale) days after sowing (DAS). The chive, coriander, and parsley seeds were sown in the furrows in August 26, 2015 (eight days before the transplanting of kale plants). Coriander has shorter crop cycle than the other crops used, thus, two consecutive crops of coriander were used during the experiment period. Seeding of the second cycle of coriander was performed one day after harvesting the first crop. The cultivars used were Manteiga de Georgia (kale), Verdão (coriander), Todo Ano (chives), Graúda Portuguesa (parsley), and Italiano (basil).

Cover fertilization was performed biweekly during the experiment, starting at 15 days after transplanting (DAT) of the kale seedlings, with 1.5 $\mathrm{kg} \mathrm{m}^{-2}$ of the organic compost in all treatments. A micro sprinkler irrigation system was used, with two irrigations per day. Weeding was performed when necessary. No pesticides were applied.

Kale were harvested at 41, 56, and 70 DAT. Basil was harvested at 36, 51, and 70 DAT. The leafy, flowering branches of basil plants were cut with a pruning shear at a height of $30 \mathrm{~cm}$ from the ground in each harvest. Coriander plants were harvested at 35, and 36 DAS in the first and second 
production cycles, respectively. Parsley plants was harvested at 55 DAS and chives at 70 DAS. The entire plants of coriander and parsley were harvested.

The evaluated agronomic characteristics were: fresh and dry weights of commercial leaves (length $25-30 \mathrm{~cm}$, without symptoms of pest attack and diseases) of kale; and shoot fresh and dry weights of the spice crops. The fresh weights were determined using a precision balance. The fresh materials of the crops were packed in paper bags and placed in a forced-air circulation oven at $65^{\circ} \mathrm{C}$ until constant weight to evaluate their dry weight using a precision scale.

The biological efficiency of the components of the intercropping systems was calculated using land use efficiency index, relative contribution of the kale crop to the LUE, area time equivalent ratio, and system productivity index, and production advantage.

The land use efficiency index (LUE) was calculated according to the equation proposed by Willey (1979):

$$
\mathrm{LUE}=\frac{\mathrm{Yab}}{\mathrm{Yaa}}+\frac{\mathrm{Yba}}{\mathrm{Ybb}}=\mathrm{Ia}+\mathrm{Ib}
$$

wherein $\mathrm{Yab}$ is the production of crop a (kale) intercropped with crop b (spice species), Yba is the production of crop $b$ (spice species) intercropped with crop a (kale), Yaa is the production of crop a (kale) in monoculture, $\mathrm{Ybb}$ is the production of crop $\mathrm{b}$ (spice species) in monoculture, and $\mathrm{Ia}$ and $\mathrm{Ib}$ are the individual respective yields of kale and spice crops.

LUE values are smaller, or greater than 1.0. LUE $>1$ indicates a production advantage; LUE $=1$ indicates no production advantage; and LUE $<1$ indicate a production disadvantage of the crop system evaluated (WILLEY, 1979).

The relative contribution of the kale crop to the LUE (RCC) was calculated by the ratio between the individual relative productivity (I) of leaf kale and the total LUE of the system, according to the equation proposed by Souza and Macedo (2007):

$$
\mathrm{RCC}=\frac{(\mathrm{I} \times 100)}{\mathrm{UET}}
$$

wherein I is the individual relative productivity, and LUE is the land use efficiency index.

Although LUE is a good indicator of the efficiency of intercropping systems, it does not consider the time factor, i.e., the number of days that a particular crop will occupy the growing area. Thus, the LUE can overestimate the production advantages, particularly when the intercropped crops present great difference in time of production cycle (period from planting to harvesting) (PINTO et al., 2011). This problem was overcome by calculating the area time equivalent ratio (ATR) using the equation proposed by Hiebsch and McCollum (1987):

$$
\mathrm{ATR}=\frac{(\mathrm{UETa} \times \mathrm{Ta})+(\mathrm{UETb} \times \mathrm{Tb})}{\mathrm{Tab}}
$$

wherein LUEa and LUEb are the partial yield of the efficient use of the land of the crops a (kale) and b (species spice); $\mathrm{Ta}$ and $\mathrm{Tb}$ are the number of days from planting to harvest of crops a (kale) and $b$ (spice species); and Tab is the total time (days) used in the intercropping system (kale and spice).

An ATR $>1$ indicates production advantage of the evaluated intercrop; an ATR $=1$ indicate no production advantage; and an ATR $<1$ indicate production disadvantage, not justifying the crop combination for increasing yield (PINTO; PINTO, 2012). In general, ATR is similar to LUE when the intercrop period is similar to the production cycle of the crops involved, lower than LUE when the intercrop period is longer than the individual crop cycle, indicating inefficient use of resources over time, and higher ATR than LUE when the duration of the intercrop is shorter than the production cycle of the crops, indication greater efficiency of the use of production factors in the time, allowing more harvests during a time interval.

The system productivity index (SPI) standardizes the yield of the secondary crop in relation to the main crop; it was calculated according to the equation described by Odo (1991):

$$
\mathrm{SPI}=\left(\frac{\mathrm{Ybb}}{\mathrm{Yaa}}\right) \times \mathrm{Yab}+\mathrm{Yba}
$$

wherein Yaa is the yield of crop a (kale) in monoculture; Ybb is the yield of crop $b$ (spice species) in monoculture; Yab is the yield of crop a (kale) in the intercrop; and Yba is the yield of crop b (spice species) in the intercrop.

The production advantage (PRA) was calculated according to the equation proposed by Willey (1979):

$$
\mathrm{PRA}=\frac{\mathrm{RB} \times(\mathrm{UET}-1)}{\mathrm{UET}}
$$

wherein $G P$ is the gross income from the system representing the value of the production of the intercrop system; and $L U E$ is the land use efficiency index.

The gross income (GI) was obtained by multiplying the fresh weight production of the crop of each treatment by the average value of the product in the Ceará food supply centers in January 2016 (R\$ 3.00 per $\mathrm{kg}$ for chives and coriander, and $\mathrm{R} \$ 6.00$ per $\mathrm{kg}$ for kale, basil, and parsley). 
The agronomic characteristics of kale was evaluated using all five treatments with this species. The agronomic characteristics of chives, basil, and parsley was evaluated using individual comparison for each species between the two treatments (monoculture and intercrop). The agronomic characteristics of coriander was evaluated using a joint analysis involving the crop systems in a $2 \times 2$ factorial arrangement. The data were subjected to analysis of variance (F-test), and the Tukey's test at $5 \%$ probability for comparison of means. Statistical analyzes were performed using the Genetics and
Statistics GENES program (CRUZ, 2013).

\section{RESULTS AND DISCUSSION}

The cropping systems had significant effect on the fresh and dry weights of commercial leaves of kale plants (Figures 2 and 3). These weights were higher when using the intercrop of kale with parsley when compared to the other intercrops, but not differing from those of the kale in monoculture.

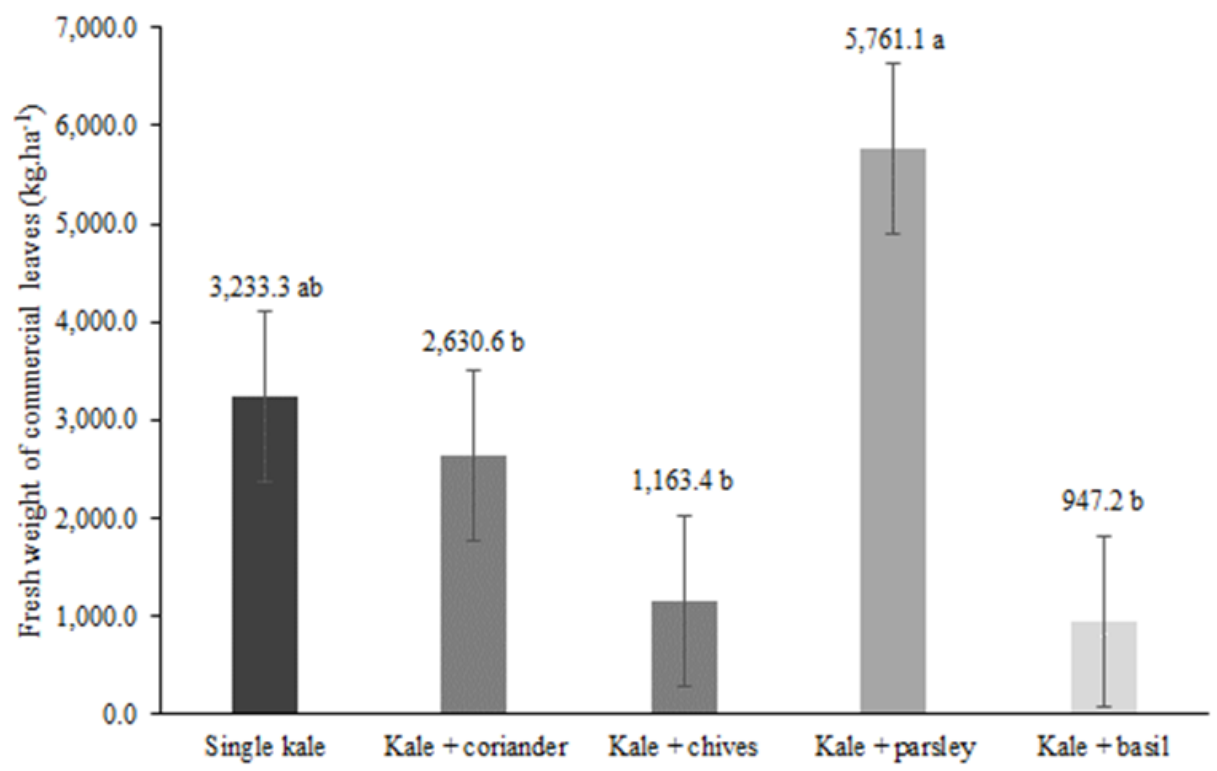

Figure 2. Fresh weight of commercial leaves of kale plants grown singly and intercropped with spice plants. Means followed by the same letter in the columns do not differ by the Tukey's test at $5 \%$ probability.

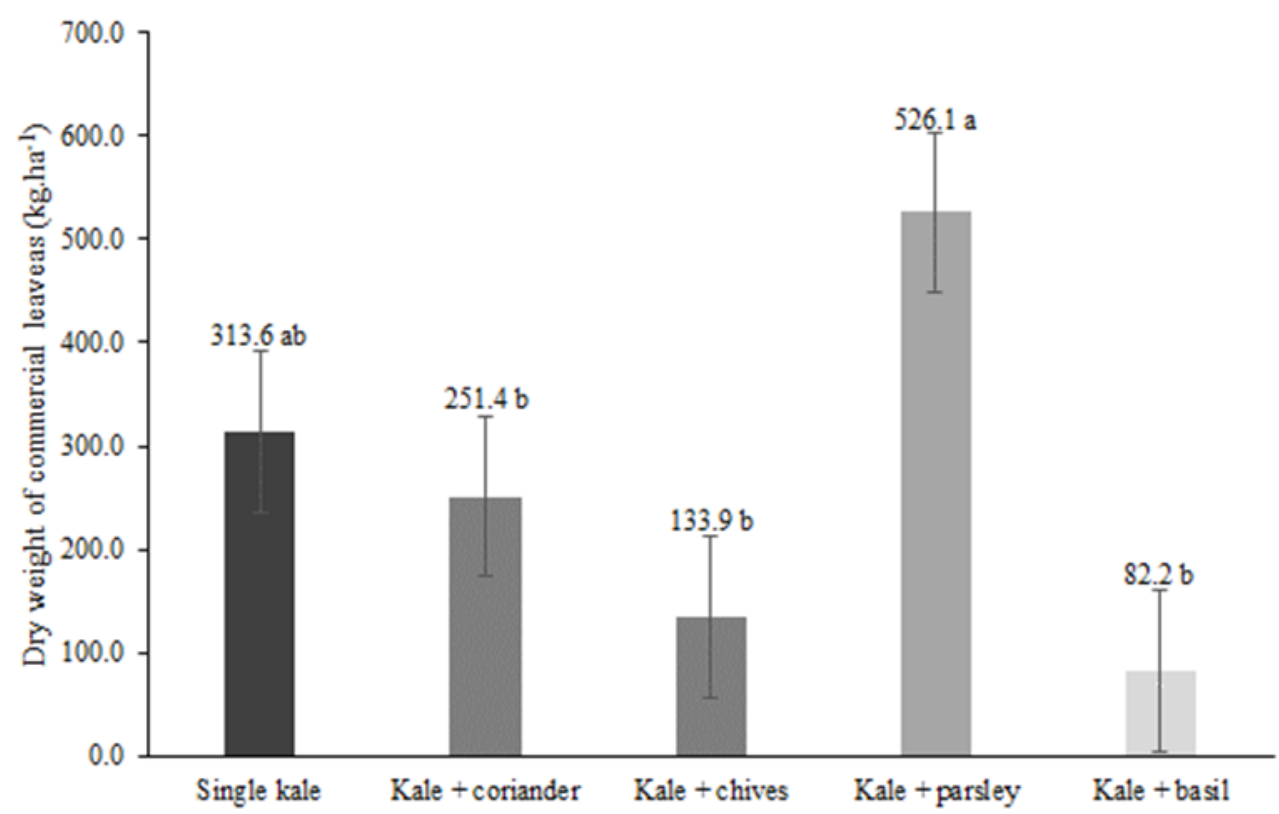

Figure 3. Dry weight of commercial leaves of kale plants grown singly and intercropped with spice plants. Means followed by the same letter in the columns do not differ by the Tukey's test at 5\% probability. 
A. R. A. A. HENDGES et al.

The greater fresh weight of kale leaves in the intercrop with parsley can be explained by the slower growth of the spice species when compared to the kale, which generated less competitive interference in this intercrop. Thus, parsley was the spice species that had more complementarity to kale when considering the use of productive resources.

The fresh weight of commercial leaves of kale in all crop systems was approximately $57.0 \%$ of the total fresh weight of the leaves harvested in the area (data not shown). This low quality of kale leaves was, in general, due to severe attack of aphids (Myzus persicae), which significantly weakened kale plants, and consequently reduced leaf quality. Considering these conditions, the best performance of the intercrop of kale with parsley was also due to the lower number of aphids found in kale plants in this treatment (data not shown). Parsley plants probably regulated the aphid population by repelling the pest, or attracting natural enemies, thus optimizing the natural control of this pest and generate smaller quality losses of the kale leaves.

A lower number of aphids was found in intercropped coriander plants with kale (data not shown), but fresh weight of kale leaves decreased $18.6 \%$ in this intercrop when compared to the monoculture. This result can be explained by the competition pressures due to shading caused by coriander plants on kale plants in the initial development stages after transplanting. In general, plant yield depends on the biosynthesis and distribution of biomass (CECILIO FILHO et al., 2011), which are negatively affected by low availability of light (TAIZ; ZEIGER, 2013).

Similar results were found by Resende et al. (2010), they found a reduction of approximately $15.3 \%$ in leaf fresh weight of kale plants intercropped with coriander when compared to the monoculture. Similarly, Choudhuri and Jana (2012) evaluated cabbage (Brassicaceae) and coriander crops and found higher fresh weight $(17.6 \%)$ in the monoculture when compared to the intercrop. This denotes a competition involving Brassicaceae (kale and cabbage) and coriander plants.

The fresh and dry weight of the spice crops is shown in Tables 1 and 2. The interaction between the crop systems and productive cycles had no significant effect on the agronomic characteristics of the coriander. The crop systems had significant effect only for basil, with better results for the monoculture when compared to the intercrop.

Table 1. Shoot fresh weight (SFW) and shoot dry weight (SDW) of chive, coriander, basil and parsley plants grown singly or intercropped with kale plants.

\begin{tabular}{lccc}
\hline \multirow{2}{*}{ Crop System } & \multicolumn{2}{c}{ Evaluated parameters } \\
\cline { 2 - 4 } & \multicolumn{2}{c}{ SFW $\left(\mathrm{kg} \mathrm{ha}^{-1}\right)$} & \multicolumn{2}{c}{ SDW $\left(\mathrm{kg} \mathrm{ha}^{-1}\right)$} \\
\hline Chives monoculture & $10,600.0$ & $\mathrm{~ns}$ & $\mathrm{n}$ \\
Chives intercropped & $9,710.0$ & & 896.7 \\
\hline Coriander monoculture & $37,558.0$ & $\mathrm{~ns}, 296.8$ \\
Coriander intercropped & $36,245.8$ & & $13,297.1$ \\
\hline Basil monoculture & $21,022.1$ & $\mathrm{a}$ & $\mathrm{a}, 116.1$ \\
Basil intercropped & $16,128.9$ & $\mathrm{~b}$ & $1,617.1$ \\
\hline Parsley monoculture & $9,433.3$ & $\mathrm{~ns}$ & $1,308.3$ \\
Parsley intercropped & $9,710.0$ & & $1,305.0$ \\
\hline
\end{tabular}

Means followed by the same letter in the columns do not differ by the $\mathrm{F}$ test at $5 \%$ probability.

The basil fresh weight in the intercropping system was lower than that in the monoculture, although the amount of fresh weight per plant was similar between the systems (data not presented). This result was expected due to the different populations of basil plants between the monoculture and intercropping systems, the latter had 50\% less plants than the monoculture. This lower number of basil plants in the intercrop system resulted in a fresh weight $23.3 \%$ lower. Vieira et al. (2012) evaluated different population densities of basil plants grown singly or intercropped with lettuce and also found higher fresh leaf weight due to the greater number of plants per area.

These results show the influence of population density on the crop production components. The use of low population can reduce productivity per area, and the excessive number of plants generate interspecific competition. Moreover, the peculiarities of each system should be considered because the choice of the crop population in intercropping systems is important to improve productivity.

The intercrops were tested as alternatives to improve the land use of the main species and increase the profitability of the area by the addition of other species between the kale rows.

Significant differences in fresh and dry weight were found between the coriander cycles (Table 2). The first cycle of coriander had greater biomass accumulation due to less competition for productive resources, since kale plants presented, in general, slower growth in the post-transplant period. Kale plants had higher heights during the second cycle of coriander plants, thus, kale plants caused shading on coriander plants during this period, intercepting part of the light that before reached more intensity the coriander plants. 
A. R. A. A. HENDGES et al.

Table 2. Shoot fresh weight (SFW), and shoot dry weight (SDW) of coriander plants grown in monoculture and intercropping systems in two production cycles.

\begin{tabular}{lcccc}
\hline \multirow{2}{*}{ Production Cycle } & \multicolumn{3}{c}{ Evaluated parameters } \\
\cline { 2 - 5 } & \multicolumn{2}{c}{ SFW $\left(\mathrm{kg} \mathrm{ha}^{-1}\right)$} & $\mathrm{SDW}\left(\mathrm{kg} \mathrm{ha}^{-1}\right)$ \\
\hline $1^{\text {st }}$ Cycle & $33,710.0$ & $\mathrm{a}$ & $3,140.8$ & $\mathrm{a}$ \\
$2^{\text {nd }}$ Cycle & $12,000.0$ & $\mathrm{~b}$ & $1,296.9$ & $\mathrm{~b}$ \\
\hline
\end{tabular}

Means followed by the same letter in the columns do not differ by Scott-Knott test at $5 \%$ probability.

Grangeiro et al. (2011) evaluated an intercrop of coriander with beetroot and found that the sowing of coriander at 14 days after the sowing of the beetroot generated reduction of fresh biomass of coriander when compared to the treatment with simultaneous sowing.

All intercrops presented efficient use of land (LUE) higher than the base unit (1.00); i.e., presented better production than the kale monocultures. The highest efficiency indexes were found for chives, coriander, and parsley; areas 33\%, $84 \%$, and $181 \%$ larger would be needed for these monocultures to reach the same production of the intercrops. Resende et al. (2010) observed LUE of 1.92 for intercrop of kale with coriander.

Table 3. Efficient land use index (LUE), relative contribution of kale crop to LUE (RCC), area time equivalent ratio (ATR), system productivity index (SPI), and production advantage (PRA) of kale plants grown singly, or intercropped with spice species (chives, coriander, basil, and parsley).

\begin{tabular}{lccccc}
\hline Crop Systems & LUE & RCC $(\%)$ & ATR & SPI $\left(\mathrm{kg} \mathrm{ha}^{-1}\right)$ & PRA (R\$) \\
\hline Kale monoculture & 1.00 & - & - & $3,233.20$ & - \\
Kale + Coriander & 1.78 & 45.7 & 1.40 & $5,750.94$ & $54,807.52$ \\
Kale + Chives & 1.28 & 28.2 & 1.44 & $4,125.22$ & $7,807.52$ \\
Kale + Parsley & 2.81 & 63.38 & 3.86 & $9,089.60$ & $59,805.55$ \\
Kale + Basil & 1.06 & 27.63 & 1.09 & $3,427.90$ & $3,069.55$ \\
Coriander monoculture & 1.00 & - & - & - & - \\
Chive monoculture & 1.00 & - & - & - & - \\
Parsley monoculture & 1.00 & - & - & - & - \\
Basil monoculture & 1.00 & - & - & - & - \\
\hline
\end{tabular}

The greater efficiency of the intercrop of kale with parsley occurred probably due to the interaction between these crops, which increased the kale production. This is confirmed by the kale RCC, higher than $63 \%$ for the LUE (Table 3). According to Willey (1990), the highest efficiencies of intercropping systems are achieved with species that do not affect negatively each other, generating a better use of the available resources and allowing the intercrop to produce more than its crops in monoculture.

The intercrop of kale with coriander reached a LUE of 1.78 mainly due to the two coriander production cycles, since kale participated with $45.7 \%$ of the total efficiency of the intercrop. Thus, the kale production when intercropped with coriander was offset by the greater production of the spice crop.

The calculated ATR were, in general, higher than the LUE for all treatments, except for the coriander intercrop (Table 3). The high ATR of the intercrop of kale with parsley (3.86), and kale with chives (1.44), were due to the shorter duration of the intercrop when compared to the kale production cycle. This denotes the possibility of maximizing the production per area, with a lower consumption of productive resources over time, making a more sustainable agriculture through these systems.

The intercrops with the greatest SPI were those of kale with parsley, and kale with coriander, which had significant increases in fresh weight when compared to the kale monoculture (Table 3). The agronomic gains were approximately $181.13 \%$ (kale with parsley) and $77.8 \%$ (kale with coriander), which generated a greater profit, with values above $\mathrm{R} \$$ 54,000.00. In general, these results show the superiority in the land use efficiency achieved by the intercropping systems, i.e., greater agronomic advantage, and economic gains.

\section{CONCLUSION}

The intercrop of kale with parsley had the best agronomic performance, land use efficiency, and productive stability, due to the higher productivity of the main crop and the absence of damages to the spice crop production.

Considering the land use efficiency index, the intercrop of kale with coriander is also a viable alternative. However, an appropriate time for the establishment of the intercrop is necessary to balance the use of the environmental resources.

\section{REFERENCES}

AlBuQUERQUE, J. A. A. et al. Cultivo de 
mandioca e feijão em sistemas consorciados realizado em Coimbra, Minas Gerais, Brasil. Revista Ciência Agronômica, v. 43, n. 3, p. 532-538, 2012.

ALVARES, C. A. et al. Köppen's climate classification map for Brazil. Meteorologische Zeitschrift, v. 22, n. 6, p. 711-728, 2013.

BIANCO, M. S. Viabilidade agroeconômica do consórcio de couve com espinafre 'Nova Zelândia'. 2015. 55 f. Tese (Doutorado em Agronomia: Área de Concentração em Produção Vegetal) - Universidade Estadual Paulista, Jaboticabal, 2015.

BRINTHA, I.; SERAN, T. H. Effect of paired row planting of radish (Raphanus sativus L.) intercropped with vegetable amaranthus (Amaranthus tricolor L.) on yield components of radish in sandy regosol. The Journal of Agricultural Sciences, v. 4, n. 1, p. 19-28, 2009.

BROOKER, T. S. et al. Improving intercropping: a synthesis of research in agronomy, plant physiology and ecology. New Phytologist, v. 206, n. 1, p. 107117, 2015.

CARVALHO, L. M. et al. Produtividade do tomateiro em cultivo solteiro e consorciado com espécies aromáticas e medicinais. Horticultura Brasileira, v. 27, n. 4, p. 458-464, 2009.

CECÍLIO FILHO, A. B. et al. Agronomic efficiency of intercropping tomato and lettuce. Anais da Academia Brasileira de Ciências, v. 83, n. 3, p. 1109-1119, 2011.

CECÍLIO FILHO, A. B. et al. Economic analysis of the intercropping of lettuce and tomato in different seasons under protected cultivation. Horticultura Brasileira, v. 28, n. 3, p. 326-336, 2010.

CHOUDHURI, P.; JANA, J. C. Effect of intercropping on yield and economics of cabbage. Journal of Crop and Weed, v. 8, n. 1, p. 155-157, 2012.

CRUZ, C. D. GENES - A software package for analysis in experimental statistics and quantitative genetics. Acta Scientiarum Agronomy, v. 35, n.3, p. 271-276, 2013.

SANTOS, H. G. et al. Sistema brasileiro de classificação de solos. 3. ed. Brasília, DF: Embrapa, 2013. 353 p.

FONSECA, J. R. O. Cultivos consorciados entre alface, cenoura, manjericão e melissa. 2009. $151 \mathrm{f}$. Dissertação (Mestrado em Ciências Agrárias: Área de Concentração em Agroecologia) - Universidade
Federal de Minas Gerais, Montes Claros, 2009.

GRANGEIRO, L. C. et al. Avaliação agroeconômica das culturas da beterraba e coentro em função da época de estabelecimento do consórcio. Revista Ciência Agronômica, v. 42, n. 1, p. 242-248, 2011.

HIEBSCH, C. K.; MCCOLLUM, R. E. Area x time equivalency ratio: a method of evaluating the productivity of intercrops. Agronomy Journal, v. 79, n. 1, p. 15-22, 1987.

MARKOVIC, D. Crop Diversification Affects Biological Pest Control. Agroznanje, v. 14, n. 3, p. 449-459, 2013

MONTEZANO, E. M.; PEIL, R. M. N. Sistemas de consórcio na produção de hortaliças. Revista Brasileira Agrociência, v. 12, n. 2, p. 129-132, 2006.

MORAES, A. A. et al. Produção da capuchinha em cultivo solteiro e consorciado com os repolhos verde e roxo sob dois arranjos de plantas. Ciência e Agrotecnologia, v. 32, n. 4, p. 1195-202, 2008.

MOUSAVI, S. R.; ESKANDARI, H. A. General overview on intercropping and its advantages in sustainable agriculture. Journal of Applied Environmental and Biological Sciences, v. 1, n. 11, p. 482-486, 2011.

ODO, P. E. Evaluation of short and tall sorghum varieties in mixtures with cowpea in the Sudan savanna of Nigeria: land equivalent ratio, grain yield and system productivity index. Experimental Agriculture, v. 27, n. 4, p. 435-441, 1991.

OHSE, S. et al. Viabilidade agronômica de consórcios de brócolis e alface estabelecidos em diferentes épocas. Idesia, v. 30, n. 2, p. 29-37, 2012.

OLIVEIRA, E. Q. et al. Produtividade de alface e rúcula, em sistema consorciado, sob adubação orgânica e mineral. Horticultura Brasileira, v. 28, n. 1, p. 36-40, 2010.

PINTO, C. M. et al. Produtividade e índices competição da mamona consorciada com gergelim, algodão, milho e feijão caupi. Revista Verde de Agroecologia e Desenvolvimento Sustentável, v. 6, n. 2 , p. $75-85,2011$.

PINTO, C. M.; PINTO, O. R. O. Avaliação da eficiência biológica e habilidade competitiva nos sistemas de consorciação de plantas. Enciclopédia Biosfera, v. 8, n. 14, p. 105-122, 2012.

RESENDE, A. L. S. et al. Consórcio couve-coentro em cultivo orgânico e sua influência nas populações 
de joaninhas. Horticultura. Brasileira, v. 28, n. 1, p. 41-46, 2010.

SOUZA, J. P.; MACEDO, M. A. S. Análise de viabilidade agroeconômica de sistemas orgânicos de produção consorciada. ABCustos Associação Brasileira de Custos, v. 2, n. 1, p. 57-78, 2007.

TAIZ, L.; ZEIGER, E. Fisiologia Vegetal. 5. ed. Porto Alegre, RS: Artmed, 2013. 954 p.

VIEIRA, M. C. et al. Consórcio de manjericão (Ocimum basilicum L.) e alface sob dois arranjos de plantas. Revista Brasileira de Plantas Medicinais, v. 14, Sup., p. 169-174, 2012.

WILLEY, R. W. Intercropping: its importance and research needs. Part 1: Competition and yield advantagens. Field Crop Abstracts, v. 32, n. 1, p. 1$10,1979$.

WILLEY, R. W. Resource use in intercropping systems. Agricultural Water Management, v. 17, n. 1-3, p. 251-231, 1990 